Jurnal Scripta Teologi dan Pelayanan Kontekstual
ISSN 2086-5368 (Print)
ISSN
Http://ejournal.stte.ac.id
Vol.3, No.2, pp. 184-204, 2018

\title{
Pengenalan Akan Nama Allah Sebagai Peneguhan Iman Dalam Masa Kesesakan
}

\begin{tabular}{|c|c|}
\hline \multicolumn{2}{|r|}{$\begin{array}{c}\text { Sri Wahyuni } \\
\text { STT Ebenhaezer Tanjung Enim,Yunikusradi@gmail.com }\end{array}$} \\
\hline INFO ARTIKEL & \multirow{8}{*}{$\begin{array}{l}\text { ABSTRAK } \\
\text { Tak pelak lagi pada masa-masa ini banyak kesesakan yang dialami } \\
\text { oleh orang Kristen. Terbatasnya pengenalan akan nama Allah yang } \\
\text { berkuasa merupakan salah satu penyebab orang Kristen jadi undur } \\
\text { imannya kepada Tuhan. Sebagaimana Allah telah mendampingi Israel } \\
\text { dalam masa kesesakan yang sangat di Mesir dan menyatakan Nama Diri } \\
\text { Allah sebagai Allah yang Maha Kuasa, maka Allah yang sama yang } \\
\text { menyatakan nama-Nya kepada Musa juga akan menguatkan umat-Nya } \\
\text { pada masa kini. Allah menyatakan nama-Nya kepada Musa sebagai agen } \\
\text { yang diutus Allah untuk meneguhkan umat-Nya, menyatakan bahwa } \\
\text { Israel adalah umat kepuinyaan-Nya sendiri. Nama YHWH menyatakan } \\
\text { bahwa Diri-Nya ada dan berkuasa untuk membebaskan umat-Nya. } \\
\text { YHWH adalah Allah yang telah menyertai nenek moyang mereka dan } \\
\text { setia kepada perjanjian-Nya. Dan karena itu YHWH menuntut respos } \\
\text { umat untuk mengingat nama itu selama-lamanya dan menyebut nama- } \\
\text { Nya secara turun-temurun. Melalui pengenalan akan nama Allah yaitu } \\
\text { Yahweh yang selalu Ada dan berkuasa itu maka umat Kristen masa kini } \\
\text { bahkan akan menjadi lebih tahan dalam masa kesesakan karena Allah } \\
\text { selalu ada dalam hidup umat sampai maranatha. }\end{array}$} \\
\hline el: & \\
\hline 18 & \\
\hline 8 & \\
\hline $\begin{array}{l}\text { Disetujul: } 2 C \\
\text { Dipublikasi: }\end{array}$ & \\
\hline Iman, Kesesa & \\
\hline $\begin{array}{l}\text { Keywords: } \\
\text { keyword one, keyword } \\
\text { two, keyword three. }\end{array}$ & \\
\hline & \\
\hline
\end{tabular}

\section{ABSTRACT}

Inevitably during these times many tribulations are experienced by Christians. Limited knowledge of the name of God who is in power is one of the reasons why Christians are withdrawing from their faith in God. Just as God had accompanied Israel in a time of great distress in Egypt and revealed God's Name as Almighty God, then the same God who revealed His name to Moses would also strengthen His people today. God revealed His name to Moses as an agent sent by God to strengthen His people, stating that Israel was His own people. The name YHWH states that He exists and has the power to deliver His people. YHWH is a God who has accompanied their ancestors and is faithful to His covenants. And because of that YHWH demands the respect of the people to remember that name forever and chant His name for generations. Through the knowledge of God's name, Yahweh, who is always there and in power, Christians today will even be more resilient 


\section{Pendahuluan}

Penyertaan Allah terhadap umat-Nya tidak pernah berhenti, karena la setia. Namun seringkali kesusahan hidup membuat keberadaan Allah seakan-akan kabur. Manusia seringkali membuat penderitaannya lebih besar dari pada Allah. Allah adalah setia dan telah membuktikannya melalui karya-Nya. Penderitaan manusia akan semakin kompleks seiring dengan perkembangan zaman. Melihat hal ini penulis melalui karya tulis ini tergerak untuk mengingatkan orang percaya akan Allah yang besar yang telah menyatakan diri melalui nama-Nya.

Penderitaan, penindasan dan penganiayaan merupakan hal yang tidak asing dalam kehidupan kekristenan. Di satu sisi penderitaan mampu menguatkan iman orang percaya, umat Allah yang tangguh lahir dari proses sejarah yang penuh perjuangan. Namun tidak sedikit pula umat percaya yang akhirnya menyangkali iman mereka karena tekanan yang mereka hadapi. Banyak orang Kristen menjual Kristus karena kemiskinan, pendidikan dan faktor kesulitan hidup yang lain.

Salah seorang mahasiswa Sekolah Tinggi Theologia Ebenhaezer yang berinisial AM, menceritakan bahwa di daerah kelahirannya, banyak pemuda yang menyangkali iman mereka, berganti agama demi mendapat pendidikan sekaligus dana pendidikan. Pemuda-pemudi Kristen di daerahnya, dijanjikan sekolah gratis dan dibawa keluar daerah, asalkan mereka mau menyangkal iman mereka. Iman terhadap Yesus Kristus tampaknya menjadi sesuatu yang amat tidak berharga sehingga dengan sangat mudah ditukar dengan kemapanan.

Negara Kesatuan Republik Indonesia tidak lebih baik jika berbicara mengenai perlindungan terhadap umat percaya meski berazaskan Pancasila yang di dalamnya terkandung toleransi terhadap ke- bhinekaan, namun sejujurnya pemerintahan bangsa ini masih lebih memihak kepada kelompok agama mayoritas. Kegiatan orang Kristen terbatas, seperti izin pembangunan rumah ibadah yang sangat sulit, penyegelan dan bentuk ketidakadilan lain yang masih sangat terlihat di bangsa ini. Bangsa ini masih harus terus belajar makna dari sebuah toleransi. Dalam tekanan-tekanan inilah satu persatu orang Kristen menyerah kepada keadaan, mengikuti arus, mencari aman dengan mempertaruhkan apapun termasuk iman mereka.

Dunia internasional saat ini sedang menghadapi sebuah fenomena penyiksaan mengerikan yang didalangi oleh sebuah organisasi ekstrem yang menamakan diri mereka Islamic State in Iraq and Syriah lebih dikenal dengan sebutan ISIS. Gerakan ini berambisi untuk menjadikan negara-negara Islam bersekutu dalam satu kekalifahan. Untuk mencapai ambisi itu mereka menghalalkan segala cara bahkan tega membunuh siapapun yang menentang mereka. Dimulai dengan menggunggah video mereka ke situs Youtube, di mana dalam video itu terlihat sekitar lima puluh kepala manusia yang diperkirakan kepala dari tentara Suriah ditancapkan pada pagar- pagar besi. Running teks di sebuah stasiun televisi swasta pada tanggal 17 Agustus 2014 pukul 19.00 WIB mencatat bahwa sekitar 1.500 orang suku Sheitat di Suriah dibantai oleh tentara ISIS. Tercatat 200 tentara Suriah menghilang, dalam suatu serangan tentara ISIS menewaskan ribuan warga sipil di Irak, mengubur hidup-hidup 300 orang di Irak bahkan mengeluarkan ultimatum pada tanggal 10 Juni 2014 yang memaksa umat Kristen Irak untuk tunduk dalam pemerintahan mereka dan menyangkali iman mereka 
terhadap Yesus Kristus, jika tidak mereka diancam akan dibunuh. Ideologi gerakan ini didukung oleh banyak basis massa di dunia. Situs shotusalam.com mencatat ada 12 organisasi jihad international mendukung gerakan ini. Di Indonesia meski agak terselubung tampaknya dukunganpun terus ditujukan pada gerakan ini. Masyarakat Irak dan Suriah saat ini sedang dalam masa kesusahan besar mereka disebabkan serangan brutal dari organisasi yang dipimpin oleh Abu bakar Al baghdadi ini.

Kenyataan yang sangat menakutkan, namun tidak dapat dihindari. Tanda- tanda datangnya masa kesusahan besar telah tampak dan mampu membuat banyak orang menyangkali iman mereka. Penulis yakin bahwa ketika masa kesusahan besar atau tribulasi terjadi kelak, maka akan timbul kemurtadan besar di muka bumi ini. Akan banyak orang percaya yang menyerah terhadap kesusahan dan memilih untuk menyangkali iman mereka kepada Tuhan Yesus karena pada masa tribulasi penderitaan dan tekanannya akan lebih kompleks dan mengerikan. Seperti yang digambarkan Welly Pandensolang dalam bukunya Eskatologi yang Biblika, bahwa:

Masa Tribulasi atau kesusahan besar sangat berbeda dari semua masa penyiksaan, penganiayaan dan penderitaan yang pernah terjadi sejak dunia dijadikan hingga saat ini, baik dari segi sifat, kejadian, serta kualitasnya. Daniel dan Tuhan Yesus menjelaskan bahwa penderitaan itu belum pernah terjadi sejak zaman dunia dimulai dan tidak akan terjadi lagi setelah zaman tersebut (Dan. 12: 1, Mat 24:21).

Pada masa Perjanjian Lama, peristiwa penderitaan yang dahsyat dalami oleh bangsa pilihan Allah yaitu Israel. Dimana bangsa ini ditindas dalam penderitaan yang sangat berat sebagai bangsa yang diperbudak oleh Mesir. Hidup sebagai budak jelas merupakan hal yang sangat tidak menyenangkan. Seorang budak tidak lagi memiliki hak atas dirinya sendiri. Jika tuannya tidak mengiginkan seorang budak dapat dijual. Hukuman cambuk hingga daging terlepas akan dialami budak yang tidak menunjukan kinerja yang baik. Untuk bangsa Israel penderitaan yang harus mereka tanggung lebih berat lagi, dimana mereka harus mengalami genocida atau pemusnahan Ras dengan membunuh setiap anak laki-laki yang lahir dari Rahim wanita Israel (Kel. 1: 22). Bayi-bayi yang seharusnya menjadi generasi penerus, dibuang ke sungai Nil. Laju pertumbuhan umat Israel pun dicegah. Penderitaan umat Allah itu dituliskan dalam sebuah prasasti, "Israel telah hancur, bibitnya terhapus", "dan setiap orang dari suku pengembara telah dikekang oleh raja Mernepatah". Bukti bahwa apa yang dirasakan umat Israel benar-benar pernah terjadi dan tercatat dalam sejarah Mesir.

Keadaan ini membuat bangsa Israel berteriak pilu kepada Allah mereka. Teriakan yang diserukan dalam kepedihan yang teramat dalam itulah yang sampai kepada Tuhan. Dengan penggunaan bentuk consecutif imperfect menunjukkan bahwa teriakan yang seperti ini belum pernah dilakukan sebelumnya, bangsa Israel sedang ada dalam penderitaan yang luar biasa sehingga mengharuskan mereka berteriak kepada Tuhan. sangking menderitanya beberapa waktu mereka tak mampu meneriakkan derita tersebut, menyimpan kepiluan mereka dalam hati mereka. Kekejaman perbudakan Mesir tentu bukan hanya bicara mengenai kerja paksa saja melainkan pengekangan kebebasan sebuah bangsa, perampasan hak dan perendahan harga diri sebuah bangsa.

Di saat itulah Musa sebagai hamba Tuhan diperintahkan menjadi penyampai kebebasan bagi umat Israel. Sebagai seorang agen Allah diutus Tuhan untuk meyampaikan kabar pembebasan bagi umat Israel. Bangsa yang tertindas selama lebih 
dari 400 tahun saat ini sedang menyongsong kebebasannya, dan berita itu dinyatakan kepada Musa manusia yang dipercaya Allah dapat menjadi perantara-Nya menyampaikan keberadaan Allah yang akan membebaskan mereka dari perbudakan dan menuntun ke tanah perjanjian.

Begitu signifikannya peranan seorang hamba Tuhan dalam memberitakan dan memberi pemahaman tentang Allah yang bertindak dalam pergumulan umat-Nya. Maka demikian juga dengan masa tribulasi penderitaan yang berat dan kompleks ini harus diimbangi dengan pemberitaan yang benar agar umat memahami makna dari masa tribulasi sebab penderitaan pada masa ini sangat lengkap dan mengerikan penderitaan yang akan dialami manusia secara fisik, ekonomi dan alam semua seakanakan menjadi suatu "mesin penghancur" yang siap melumat manusia tak heran jika $\mathrm{H}$. L. Wilmington menuliskan demikian dalam bukunya:

Bencana merupakan teman tetap manusia sepanjang sejarah. Akan tetapi menurut Alkitab, akan datang suatu malapetaka yang lain daripada yang pernah dilihat dunia yang letih ini. Meskipun malapetaka yang akan datang relatif singkat akan berlangsung, namun memiliki kekuatan yang akan menghancurkan penduduk dunia daripada lebih banyak gabungan angka yang pernah tercatat dalam seluruh bencana alam di dunia ini. Sesungguhnya hampir satu milyar orang akan rubuh selama permulaan bencana mengerikan yang akan datang ini.

Banyak orang cukup gentar jika membayangkan apa yang terjadi, apakah umat manusia mampu bertahan dalam situasi yang mengerikan ini? Dalam kegentaran dan kepedulian penulis tergerak untuk memberikan sumbangsih dari kitab Keluaran 3:15 mengenai makna nama-nama Allah. Nama Allah yang agung itu adalah bentuk penyataan kebesaran dan kesetiaan Allah bagi umat Israel masa itu dan umat percaya masa kini. Sehingga dalam kondisi seberat apapun Allah yang besar dan setia itu tidak akan meninggalkan umat-Nya dan akan memampukan mereka melewati masa tribulasi. Dalam pemahaman yang benar mengenai nama Allah inilah berharap orang percaya dapat diteguhkan imannya dan siap dalam menghadapi masa tribulasi. Peribahasa "apalah arti sebuah nama" tidak berlaku bagi Allah.

\section{Metode Penelitian}

Penelitian ini adalah penelitian kualitatif dengan pendekatan grammatical analysis. grammatical analysis adalah "the first stage of determining the inner cohesion of the text is to analyze the relationships entween the individual units or terms in the next".(Osbone;1991:19). Paradigma yang digunakan adalah paradigma naturalistik, yang pada hakikatnya merupakan suatu upaya untuk menemukan kebenaran atau untuk lebih membenarkan kebenaran. Kebenaran yang dimaksud adalah Kebenaran konsep Integritas yang tertulis dalam Keluaran 3:15.

Teknik pengumpulan data dalam penelitian ini dilakukan dengan pengamatan atau partisipasi langsung dan penelaahan dokumen.

Analisis data yang digunakan dalam penelitian ini mengikuti langkah-langkah grammatical analysis. Langkah penafsiran yang akan ditempuh sebagai berikut: 1). Teks Keluaran 3:15 akan ditafsirkan; 2). Penafsiran tiap tiap ayat akan mengerucut kepada kalimat demi kalimat dan frasa demi frasa; 3). Penelusuran terhadap meaning dari setiap frasa akan sangat terlihat hal ini dengan Tujuan supaya dapat melihat atau mendapat sense dari meaning yang dimaksud berkenaan dengan pengenalan akan nama Allah. 


\section{Hasil Dan Pembahasan}

\section{A. Pemahaman Terhadap Nama-Nama Allah Dalam Keluaran 3:15}

YHWH ialah nama yang dinyatakan Allah sendiri kepada umat-Nya dan hal ini dituliskan didalam Alkitab yang adalah sumber dari segala kebenaran. Dalam penindasan yang dialami oleh umat pilihan, Allah menyatakan diri-Nya dengan nama YHWH. Melalui penyataan diri Allah dalam nama YHWH umat Allah diperkenankan untuk mengenal, mengetahui bahkan memanggil nama itu. Maka melalui nama itu nyata bahwa Allah ada untuk umat-Nya, bangsa pilihan yang sedang dalam penindasan akan dibebaskan oleh $\mathrm{YHWH}$ yang adalah milik mereka. Tentang hal ini telah dinyatakan oleh Allah dalam Kitab Keluaran.

\section{Pengenalan Terhadap Kitab Keluaran}

Nama kitab ini diambil dari versi septuaginta (LXX) yang memberikan judul sesuai dengan thema pokok kitab ini, yaitu "Keluaran" (Exodus, Yun). Nama kitab ini ditulis sesuai dengan thema besar dari kitab ini, yaitu keluarnya bangsa Israel dari tanah perbudakan. Untuk lebih memahami makna dari nama-nama Allah dalam kitab Keluaran 3:15 maka penulis terlebih dahulu menguraikan tentang pribadi Musa sebagai penulis kitab Keluaran dan juga menguraikan kitab Keluaran yaitu: Tujuan Penulisan, Otoritas kitab Keluaran dan Struktur Kitab. Melalui uraian ini diharapkan dapat menolong dalam memahami makna nama-nama Allah dalam kitab Keluaran 3:15.

\section{Musa penulis kitab Keluaran}

Kitab keluaran ditulis oleh Musa, hal ini diakui oleh tradisi Ibrani secara turuntemurun. Beberapa pakar beranggapan bahwa Musa hanya menulis bagian-bagian utama saja beberapa tambahan tertentu ditambahkan oleh editor-editor dikemudian hari. Pakar lain menganggap bahwa kitab Keluaran ditulis oleh pengganti Musa berdasarkan tradisi yang ditulis Musa dan Harun. Namun secara tidak langsung pandangan ini tetap mengakui Musa sebagai sumber dari dokumen tertulis ini.

Beberapa sarjana historis kritis berpendapat lebih ekstrem. Mereka memandang kitab Keluaran ialah kitab yang ditulis beberapa imam yang tidak dikenal pada periode pasca pembuangan dengan berdasarkan pada beberapa sumber yang mereka namakan sumber $\mathrm{Y}$ (Yahwis), sumber $\mathrm{E}$ (Elohis) dan sumber $\mathrm{P}$ (Priesly atau imam). Kemudian kitab ini direvisi dan dikembangkan dari abad ke-9 hingga ke-5 SM. Maka kaum historis kritis "mencurigai" integritas dan kebenaran kitab-kitab Perjanjian Lama, termasuk kitab Keluaran. Namun pandangan ini juga tidak dapat dipegang karena presuposisi dasar mereka yang menolak autentisitas dan otoritas Alkitab sebagai firman Allah.

Penulis setuju pada tradisi Yahudi yang menyatakan bahwa kitab keluaran ditulis oleh Musa, secara kompetensi Musa layak menulis semua kejadian sebab dia adalah saksi bahkan bagian dari sejarah bangsa Israel. Musa dalam persekutuannya yang erat dengan Tuhan juga secara langsung diperintahkan Allah untuk menulis "semua peristiwa” (Keluaran 17:14, 24:4, 34:27). Senada dengan pandangan tersebut Dr. F.L Baker dalam bukunya menyatakan:

Berkat tindakan Musa Israel menjadi suatu bangsa, ia adalah perantara Perjanjian Lama dengan menyampaikan undang-undang Allah pada umat Israel. Dialah yang menulis sejarah Israel dari permulaan. Pemimpin besar yang hidup dekat dengan Allah itulah rahasia kekuatannya. 
Maka dapatlah dipastikan bahwa yang menulis kitab Keluaran ialah Musa karena baik secara kompetensi maupun kerohanian, Musa dianggap layak untuk menuliskan kitab Keluaran.

Musa ialah seorang keturunan Lewi, anak dari Amram dan Yokhebed. Meski jabatan imam dari suku Lewi diteguhkan pada zaman sesudah Musa, penulis yakin Yokhebed yang menjadi inang pengasuh Musa terus mengajarkan dan menceritakan mengenai Allah Israel yang besar dan Mahamulia. Maka ketika terjadi peristiwa penyataan diri Allah dalam kitab Keluaran 3 Musa telah memeroleh gambaran dan pengenalan mengenai Allah nenek moyangnya. Musa memiliki saudara perempuan yang bernama Miryam yang kemudian memungkinkan Musa kecil diasuh oleh ibu kandungnya sebagai inang pengasuh (Kel. 2:7). Selain itu Musa juga memiliki seorang saudara laki- laki yang bernama Harun, dengan kedua saudaranya ini Musa memimpin bangsa Israel keluar dari Mesir. Dalam perjalanan istimewa Musa yang diangkat putri Mesir dari air membuat Musa masuk dalam keluarga besar kerajaan Mesir yang memungkinkan dia beroleh banyak pengalaman hidup sebagai seorang bangsawan.

Musa ialah seorang anak Ibrani yang kemudian ditemukan oleh putri Firaun dan dijadikan anak angkat putri Firaun. Maka secara tidak langsung Musa ialah cucu Firaun yang pastinya mendapat pendidikan istana. Sebagaimana anak-anak Firaun yang lain Musa tentu diajari ilmu dan budaya Mesir pada waktu itu.

Mesir pada masa lalu telah menjadi bangsa yang berkembang. Pada zaman prasejarah mereka telah memulai pelayaran untuk berdagang, selain itu juga memiliki pengairan yang baik dengan memanfaatkan sungai Nil. Hal ini menandakan bahwa peradaban mereka telah berkembang pesat, bahkan pada zaman pra-sejarah. Secara militer Mesir pada zaman Hiksos (diperkirakan pada zaman Yusuf) bahkan telah melakukan invasi militer ke daerah Asia dengan teknik militer yang tinggi, Mesir pada tahun 1970 SM diperkirakan telah menjadi negara yang sangat maju peradabannya. Maka jika peradaban sebuah negara maju dan berkembang tentu dikarenakan pendidikan yang juga berkembang, pendidikan itulah ditempuh Musa untuk menjadi seorang pemimpin.

Musa dididik Puteri Mesir dengan demikian ia dipersiapkan untuk tugasnya sebagai seorang pemimpin dari sebuah bangsa yang besar. Selain itu ia juga mendapat pendidikan dari inang pengasuhnya yang adalah ibu kandungnya, mengenai kebudayaan Israel sehingga membuat ia sadar bahwa ia adalah orang Israel dan bagaimana ia berbakti kepada Allah Israel. Musa sebagai pemimpin umat yang besar, telah dipersiapkan Tuhan dengan pola pendidikan yang baik untuk menjadi seorang pemimpin besar yang matang, bahkan siap menghadapi peperangan.

Nabi dalam konteks bangsa Israel ialah orang biasa yang kemudian mengalami perjumpaan dengan Tuhan sehingga mengalami perubahan besar dalam hidupnya. Perubahan kehidupan dan pemikiran itu dimungkinkan oleh Tuhan untuk mempersiapkan mereka melakukan pekerjaan besar yang Tuhan percayakan kepada para nabi bagi umat Israel. Sebagaimana kita tahu bahwa pengangkatan nabi dilakukan oleh Tuhan maka seorang nabi harus terus melakukan apa yang diperintahkan Tuhan, meski harus mempertaruhkan nyawa. Demikian pula Musa dalam nyala api di semak belukar dia mendapatkan penyataan Allah. Diutus untuk membebaskan bangsanya.

Dalam pengutusannya, dicatat pada kitab Keluaran beberapa kali Musa mencoba menolak pengutusan Tuhan padanya dengan berbagai argumen bahkan dicatat hingga 
Allah murka terhadap Musa (Kel. 4:14). Kemudian Allah mengutus Harun sebagai pendampingnya. Namun bagaimanapun proses itu terjadi pada Musa, ia adalah orang yang diurapi dan dipersiapkan Tuhan dari semula untuk memimpin bangsa Israel. Kisah penyelamatannya, kehidupan istananya, pelariannya, perjumpaannya dengan keluarga imam Yitro dan penyataan Allah, dipakai Tuhan untuk menjadikan Musa sebagai pemimpin besar, sebagai raja, imam dan nabi. Musa yang memimpin umat Israel dengan sangat baik dan memiliki persekutuan yang sangat erat dengan Tuhan.

\section{Tujuan Penulisan}

Kitab Keluaran merupakan sambungan antara riwayat-riwayat kitab Kejadian dengan kitab-kitab pentateuch yang menerangkan hal hukum. Di dalamnya terdapat sejarah perbudakan bangsa Mesir setelah kematian Yusuf, kemudian pelepasan mereka agar dapat menjadi umat milik Tuhan sendiri serta melayani dan memuliakan Dia. Kitab ini menjadi kitab sejarah perjalanan umat pilihan sekaligus bukti nyata penyertaan Allah yang sempurna bagi umat pilihanNya.

\section{Eksegese Keluaran 3: 15}

Eksegese merupakan suatu penelaahan yang cermat dan analitis mengenai suatu bagian Alkitab agar dapat mencapai suatu penafsiran yang bermanfaaat. Maka dengan metode ini penulis akan menggali makna yang terdapat dalam teks Keluaran pasal 3:15 untuk mendapat pemahaman yang benar terhadap nama-nama Allah.

\section{Musa Sang Agen Allah}

Agen dalam bahasa Indonesia merujuk kepada perantara atau perwakilan dapat juga diterjemahkan sebagai kaki tangan seseorang. Demikian pula dengan Musa dalam konteks ini dipercayakan Allah menjadi kaki tangan-Nya menjadi agen yang menyampaikan kehendak Allah bagi umat Israel.

Ayat 15 pada teks ini dibuka dengan kata, "Selanjutnya berfirmanlah Allah kepada Musa...". Kata "selanjutnya" (od): a going around, continuance, still, yet, again, beside merupakan kata sambung yang menunjukan keterkaitan dengan ayat sebelumnya. Maka pemaknaan ayat ini pun tidak lepas dari ayat sebelumnya (ay. 14) di mana pada ayat tersebut Allah telah menyatakan keberadaan-Nya dan pengutusan-Nya kepada Musa. Maka ayat 15 ini mempertegas status Musa sebagai agen atau wakil Allah bagi orang Israel. Musa ialah perantara Allah kepada umat Israel sebagai penyampai kebebasan mereka.

"Berfirmanlah Allah kepada Musa..." merupakan mandat atau perintah Allah sekaligus pengesahan kepada Musa untuk menjadi perantara-Nya. Berfirman yang dalam teks ini digunakan kata (amar), yang dapat diterjemahkan sebagai command say, speak, say to one self (think), intend, command, promise. Dalam bahasa Indonesia diterjemahkan sebagai kata, ucapan, bicara kepada diri sendiri, berniat, perintah dan janji. Kata amar ditemukan sebanyak 5280 kali penggunaannya tidak selalu untuk Allah, namun kata ini selalu disampaikan dalam kesadaran baik manusia maupun Tuhan. Dalam Kel. 8:27, Kej. 9:8 merujuk kepada perintah Allah yang harus dilakukan. Penggunaan kata amar pertama kali dalam kitab Perjanjian Lama ialah dalam teks Kejadian 1:3 kemudian dilanjutkan pada ayat-ayat selanjutnya dalam konteks penciptaan. Penggunaan kata menunjukkan bahwa apa yang Allah firmankan pasti terjadi. 
Kata amar sendiri ditulis dalam bentuk qal waw consecutif imperfect, yang artinya apa yang akan difirmankan sekarang telah difirmankan. Firman yang dinyatakan kepada Musa untuk kemudian disampaikan kepada umat Israel ialah suatu perintah dari Allah, pasti terjadi dan merupakan suatu perintah yang baru, belum pernah dinyatakan sebelumnya dan saat ini telah dinyatakan kepada Musa. Berita pembebasan yang telah direncanakan Allah itu yang belum pernah dinyatakan kepada siapapun kini dinyatakan kepada Musa, orang yang dipercayai Allah sebagai perantaraNya. Demikian pula diterjemahkan dalam buku Theological Wordbook of the Old Testament:

The word amar is used repeatedly by God to introduce revelation. One would suppose that this usage emphasizes that God's revelation is a spoken, transmissable, propositional, definite matter. The "word" does not make it a revelation. God gives the revelation to persons as one person imparts knowledge to another-by spoken word. The word d'bar is used in such a context also, "God spoke (d'bar) unto Noah" (Gen 8:15). The formula is frequent in Lev, "The Lord spoke (dabar) unto Moses saying (amar), speak (dabar) unto the children of Israel.

Bangsa yang tertindas selama lebih dari 400 tahun saat ini sedang menyongsong kebebasannya, dan berita itu dinyatakan kepada Musa manusia yang dipercaya Allah dapat menjadi perantara-Nya menyampaikan keberadaan Allah yang akan membebaskan mereka dari perbudakan dan menuntun ke tanah perjanjian.

\section{Musa Sang Penyambung Lidah Allah}

Musa sebagai nabi Allah dipercaya sebagai "penyambung lidah Allah", artinya menyampaikan apa yang telah disampaikan Allah kepadanya tanpa mengurangi atau menambahi, menyampaikan apa yang Tuhan firmankan secara murni.

Perintah Allah kepada Musa dibuka dengan kata "beginilah kau katakan" dalam bahasa Ibrani ditulis (Koh-toamar), yang secara literal dapat diartikan, "katakanlah ini". Kata "ini" dalam bahasa ibrani ditulis dengan kata = (koh) dalam bentuk Demonstrative adverb manner, place, or time, atau keterangan demonstratif yang merujuk pada cara/hal, tempat atau waktu. Demonstratif dalam Kamus Bahasa Indonesia memiliki pengertian mempertunjukkan segala sesuatu secara menyolok. Melalui kata koh dapat dipahami bahwa Musa diperintahkan mengatakan tepat seperti apa yang Tuhan katakan kepadanya secara jelas dan benar-benar nyata bahwa sabda yang disampaikan itu ialah kehendak Allah, Allah mengharapkan totalitas Musa sebagai penyambung lidah Allah.

Sedangkan amar seperti yang telah dijelaskan pada pembahasan sebelumnya merupakan perintah Allah yang harus terlaksana. (Koh-toamar), ditulis dalam bentuk verb qal imperfect 2nd person masculine singular homonym. Kata kerja imperfek ialah kata kerja yang merujuk kepada sesuatu yang belum selesai dan sedang dilakukan.

Perintah itu saat itu belum dilakukan oleh Musa, namun harus dilakukan tepat sama seperti apa yang Tuhan perintahkan kepada Musa. Fungsi Musa sebagai penyambung lidah Allah ialah menyampaikan berita pembebasan dan pengutusan Musa, persis sama seperti apa yang Tuhan firmankan padanya. Didalam pemberitaan Musa juga diharapkan suatu totalitas sehingga pemberitaan itu meyakinkan umat Allah. Tugas sebagai penyambung lidah Allah haruslah murni menyampaikan kehendak Tuhan saja. 


\section{Musa Diutus Oleh Allah}

Pengutusan terhadap Musa telah dinyatakan pada ayat 14 namun kemudian dipertegas oleh Allah dalam ayat 15, dengan kata (selahni) yang artinya dia telah mengutusku, dari kata dasar b (salah) yang memilki makna I, send, send away, let go, dalam bentuk verb qal perfect 3rd person masculine singular suffix 1st person common singular. Kata yang sama digunakan dalam pengutusan hamba-hamba Tuhan yang luar biasa seperti Yesaya, Yeremia dan Gideon. Bukan pengutusannya yang ditekankan dalam Alkitab melainkan Pribadi yang mengutusNya.

Kata (selahni) ditulis dalam bentuk verb qal perfect 3rd person masculine singular suffix 1st person common singular. Bentuk perfek menunjukkan bahwa pengutusan Allah telah dilakukan dengan sempurna. Dalam teks Ibrani kuno tidak menyebut waktu (tense) sebagaimana dalam bahasa negara-negara Eropa maka penggunaan bentuk perfek ini menunjuk bahwa sesuatu itu sudah dilaksanakan dan benar-benar telah terjadi. Suffix atau akhiran ganti orang pertama tunggal a (ni) merupakan kata ganti orang pertama yang menunjuk pada Musa. Pelaku pengutusan itu sendiri ialah Dia, person ketiga Tunggal, yang dalam teks ini ialah $\mathrm{YHWH}$.

Seperti yang telah penulis singgung sebelumnya, bahwa yang menjadi penekanan bukanlah siapa yang diutus melainkan Siapa yang mengutus. Allah telah benar-benar mengutus Musa, mempercayai Musa sebagai utusan-Nya dipercayakan kuasa untuk memimpin umat-Nya. Ketika ia menyatakan nama-Nya yang di dalamnya nyata kemahakuasaan-Nya maka kuasa yang sama akan memampukan Musa menjalankan tugasnya sebagai utusan Allah.

\section{Eksistensi Israel Sebagai Umat Allah}

Bangsa Israel, bangsa pilihan Allah yang berada dalam sebuah pola perjanjian yang terikat kuat antara Allah dan leluhur mereka. Panggilan yang direspons dengan iman oleh Abraham membawa berkat yang besar sehingga bangsa Israel ada hingga saat ini. Meski Israel modern baru berdiri sebagai negara mandiri pada tanggal 14 Mei 1948 namun eksistensi bangsa Israel telah ada ribuan tahun sebelum masehi. Alkitab mencatat kehidupan bangsa pilihan ini dengan berbagai dinamika kehidupan yang mereka alami. Bangsa Israel dipanggil, berdosa, dihukum, bertobat dikasihi dan kemudian berdosa lagi, namun dalam segala hal yang mereka alami Allah tidak pernah tinggal diam dan terus menjadi jawaban atas masalah mereka.

\section{Israel Umat Pilihan}

Kekhususan umat Israel sebagai umat pilihan dinyatakan melalui frasa (beni yisreel) atau dalam teks Keluaran 3:15 versi Indonesia terjemahan baru diterjemahkan dengan frasa "orang Israel". Sedangkan terjemahan King James Version menterjemahkan Children of Israel atau anak Israel. Kata Israel disematkan Allah kepada Yakub dalam Kejadian 32:28 secara harafiah diartikan "Allah bergumul". Kemudian sejak itu nama Israel dalam Perjanjian Lama dipakai menjadi sinonim untuk Yakub. Yakub sebagai bapa leluhur umat Israel yang kepadanya juga dinyatakan janji Allah terhadap umat-Nya (Kej. 35: 9-12) maka ketika Allah menyebut orang Israel, maka Allah selalu mengingat janji-Nya kepada umat itu. Mengingat janji yang pernah dinyatakan kepada bapa leluhur.

Pernyataan-pernyataan perjanjian itulah yang secara tersirat menyatakan pemilihan bangsa Israel. Bangsa ini telah dipilih dalam kekekalan dan janji penyertaan 
sudah dinyatakan jauh sebelum umat Israel menjadi sebuah bangsa. Bangsa pilihan, itulah status umat Israel maka tidak heran ketika mereka ada dalam penindasan Allah datang kepada ben yisrell, dan mengingatkan bahwa la tidak melupakan janji-Nya dan tidak mengingkari pemilihan-Nya pada bangsa itu.

\section{Dinamika Kehidupan Bangsa Israel}

Meski Israel adalah bangsa pilihan Allah bukan berarti mereka hidup terus menerus dalam kenyamanan. Ada waktu-waktu tertentu umat Israel hidup sebagai pendatang yang dihormati di Mesir karena mereka adalah keturunan dari Yusuf seorang besar yang pernah menjadi penolong bagi bangsa Mesir. Namun kebahagiaan itu sirna diganti dengan kesusahan yang amat besar ketika memerintah seorang raja baru yang tidak mengenal Yusuf (band. Kel. 1:8-11).

\section{Bangsa Israel Dalam Penindasan}

Mula-mula orang Israel di Mesir ialah orang merdeka, merasa aman hidup di negeri orang sebagai petani. Tanah Mesir yang subur menjamin kenyamanan hidup mereka. Namun kemudian kenyamanan itu sirna di zaman pemerintahan Ramses II. Kemerdekaan bangsa Israel direbut, bangsa ini dijadikan budak untuk membangun kota-kota baru. Pada masa itu bangsa pilihan Allah tersebut sampai pada perendahan dan kesengsaraan paling hebat. Umat Israel akhirnya berada pada masa-masa kesengsaraan yang berat sebagai budak.

Menurut F.L Baker,"Ketakutan utama bangsa Mesir tidak lain ialah pertumbuhan pesat bangsa ini karena berpotensi meninggalkan Mesir dan bergabung dengan bangsa lain untuk bebas." Maka tidak heran jika Firaun menghalalkan segala cara untuk menghadang laju pertumbuhan bangsa Israel. Dimulai dari pembunuhan bayi laki-laki bangsa Israel hingga pembebanan pekerjaan yang melebihi batas sehingga budak-budak banyak mengalami kematian dalam pembangunan kota, bendungan bahkan piramid. Konon ketika budak-budak selesai membangun piramid mereka semua dibunuh hal ini dikarenakan piramid dipakai juga untuk menyimpan harta para raja. Penderitaan yang berat ini membuat bangsa Israel berseru- seru, berteriak minta tolong dan mengerang kepada Allah (Kel. 2: 23-25). Penderitaan umat Allah itu dituliskan dalam sebuah prasasti, "Israel telah hancur, bibitnya terhapus", "dan setiap orang dari suku pengembara telah dikekang oleh raja Mernepatah". Bukti bahwa apa yang dirasakan umat Israel benar-benar pernah terjadi dan tercatat dalam sejarah Mesir.

\section{Bangsa Israel Memerlukan Pembebasan}

Dalam penderitaan mereka yang berat bangsa Israel, berteriak kepada Allah. Teriakan dalam konteks Keluaran 2:23 dituliskan dengan kata :(wayizeaqu) dengan kata dasar (za'aq) verb qal waw consecutif imperfect 3rd person masculine plural. Makna mendasar dari kata ini ialah : to cry for help in time of distress. Atau dalam bahasa Indonesia tangisan dalam keadaan kesedihan/ kesengsaraan. Distress memiliki makna lebih dari sekedar kesedihan atau kesengsaraan, dalam kamus Oxford distress diterjemahkan great pain, discomfort or sorrow atau sakit yang teramat sangat, ketidaknyamanan atau kesedihan. Dapat disimpulkan bahwa umat Israel sedang berteriak dalam kepedihan untuk meminta pertolongan dari Tuhan. 
Teriakan yang diserukan dalam kepedihan yang teramat dalam itulah yang sampai kepada Tuhan. Dengan penggunaan bentuk consecutif imperfect menunjukkan bahwa teriakan yang seperti ini belum pernah dilakukan sebelumnya menunjukan bahwa bangsa Israel sedang ada dalam penderitaan yang luar biasa sehingga mengharuskan mereka berteriak kepada Tuhan. Sangking menderitanya beberapa waktu mereka tak mampu meneriakkan derita tersebut. Kekejaman perbudakan Mesir tentu bukan hanya bicara mengenai kerja paksa saja melainkan pengekangan kebebasan sebuah bangsa, perampasan hak dan perendahan harga diri sebuah bangsa. Dapatlah dibayangkan teriakan pedih sebuah bangsa yang harga dirinya diinjak-injak dan hidupnya ditindas, mereka memerlukan pembebasan dan Allah adalah satu-satunya pembebas mereka. Hal senada dituliskan dalam Theological Word Book of the Old Testament:

The word is used almost exclusively in reference to a cry from a disturbed heart, in need of some kind of help. The cry is not in summons of another, but an expression of the need felt. Most frequently, the cry is directed to God.

Allah dengan perkasa memasuki gerak sejarah. Dia bertindak untuk kepentingan sejumlah budak yang sedang tidak berdaya dan Allah sendiri membuka jalan kebebasan dan suatu fondasi baru dalam kehidupan bangsa Israel. Mereka berteriak kepada Allah. Pembebasan dari perbudakan Mesir itulah kebutuhan utama mereka dan dengan pembebasan umat Israel menjadi suatu bukti nyata bahwa $\mathrm{YHWH}$ ada, dan turut bekerja dalam hidup bangsa pilihan-Nya.

\section{Bangsa Israel Harus Memasuki "Tanah Perjanjian"}

Allah meresmikan janji hak kepemilikan atas tanah perjanjian. Alkitab memperinci batas-batas yang pasti dari Israel sebagaimana yang dikatakan oleh Alllah kepada mereka (Kej. 13:14-15). Mengenai kepemilkan tanah ini John Hagee, menyatakan: "Pengukur tanah Ilahi menempatkan pancang-pancang yang asli pada tanah Yudea dan menetapkan tidak seorangpun boleh mengubah batas-batas tersebut. Umat Allah memilki hak mutlak terhadap tanah perjanjian, karena Allah memberinya." Maka tidak ada alasan apapun yang dapat menghadang umat Israel menuju tanah perjanjian.

Jauh lebih dalam Roy B. Zuck melihat pendudukan Israel di tanah Kanaan, sebagai suatu tahapan proses untuk menuntut seluruh ciptaan bagi Sang Pencipta. Tindakan Tuhan memilih umat Israel dan menuntun mereka menuju tanah perjanjian merupakan suatu runtutan penggenapan janji kepada umat Israel dan dari mereka perjanjian itu dinyatakan kepada bangsa-bangsa lain. Maka pendudukan Kanaan oleh bangsa Israel ialah suatu keharusan sebagai bagian dari penggenapan janji Allah bagi umat Israel.

\section{Allah Yang Setia Menyatakan Diri Di Masa Sulit}

Nama adalah wakil dari sebuah oknum dan dianggap sebagai bagian dari oknum tersebut. Hal yang sama juga nyata dalam pola peribadatan orang kafir yang meyakini bahwa nama dewa-dewa mereka adalah simbol dari kekuatan dan kuasa dari dewa itu sendiri. Allah yang menyatakan diri dalam kesusahan bangsa-Nya dengan nama YHWH bukan seperti dewa kafir yang unjuk kuasa, melainkan mau menyatakan kepada umatNya bahwa Allah ada. Allah melihat penindasan yang terjadi pada umat Israel dan Allah mengingat perjanjian-Nya pada leluhur umat Israel. 


\section{YHWH, Allah Yang Membebaskan}

Tetragramaton $\mathrm{YHWH}$ yang dalam pengucapannya disebutkan dengan kata Yehovah, Yehuwa atau Yahweh, merupakan nama Allah yang dinyatakan bagi umat Israel dalam kesesakan mereka. Beberapa ahli Perjanjian Lama berpendapat bahwa nama YHWH diadopsi dari dewa orang Keni dan Midian yang mana Yitro, mertua Musa menjadi salah satu imamnya. Mereka menduga nama itulah yang diadopsi Musa dikemudian hari sehingga akhirnya Musa menuliskan nama tersebut dalam kitab Pentateukh untuk menjelaskan pribadi Allah yang Mahabesar. YHWH ialah nama yang dinyatakan Allah sendiri kepada umat-Nya dan hal ini dituliskan didalam Alkitab yang adalah sumber dari segala kebenaran. Maka penulis menolak anggapan bahwa YHWH adalah nama yang diadopsi dari bangsa Keny.

Dalam penindasan yang dialami oleh umat pilihan, Allah menyatakan diri-Nya dengan nama YHWH, sebab ia berkata"... itulah nama-Ku..”. Melalui penyataan diri Allah dalam nama YHWH umat Allah diperkenankan untuk mengenal, mengetahui bahkan memanggil nama itu. Maka melalui nama itu nyata bahwa Allah ada untuk umat-Nya, bangsa pilihan yang sedang dalam penindasan akan dibebaskan oleh YHWH yang adalah milik mereka. Senada dengan ini Th.Vriezen menyatakan:

YHWH adalah Allah orang Israel, sehingga orang Israel harus selalu berurusan dengan Dia. Dialah dasar segala pengharapan Israel. Oleh karena itu Israel sebagai bangsa disebut warisan atau bahkan milik YHWH. Istilah warisan dalam PL selalu identik dengan tanah maka penggunaan istilah itu mengandung makna bahwa sebagai negeri dan sebagai bangsa Israel ialah murni milik YHWH. Disini berlaku suatu hubungan yang sah dan tidak dapat dipecahkan antara Israel dengan YHWH Allah Israel.

Dalam Keluaran pasal 3:14 Allah menyatakan dirinya sebagai "Aku adalah Aku" eyeh asher eyeh). Yang disepakati para ahli dengan makna "ada", dalam kekinian dan keakanan, hadir dan bahkan bertindak, karena ditulis dalam bentuk aktif. Demikian pula dengan $\mathrm{YHWH}$ yang berasal dari akar kata yang sama yaitu hyh (haya), memiliki makna yang sama yaitu Dia yang ada, hadir dan bertindak bagi umat pilihan-Nya. Dengan makna yang hampir sama Matthew Henry dalam bukunya mengulas makna penyataan Allah melalui nama-Nya :

1. A name that denotes what he is in himself : I am that I am. This explains his name Jehovah, and signifies, (1.) That he is self-existent; he has his being of himself, and has no dependence upon any other: the greatest and best man in the world must say, By the grace of God I am what I am; but God says absolutely-and it is more than any creature, man or angel, can say-I am that I am. Being self-existent, he cannot but be self-sufficient, and therefore all-sufficient, and the inexhaustible fountain of being and bliss. (2.) That he is eternal and unchangeable, and always the same, yesterday, today, and forever; he will be what he will be and what he is. (3.) That we cannot by searching find him out.

2. A name that denotes what he is to his people: The Lord God of your fathers hath sent me unto you. Thus God had made himself know to him, and thus he must make him known to them. (1.) That he might revive among them the religion of their fathers, which, it is to be feared, was much decayed and almost lost. This 
was necessary to prepare them for deliverance. (2.) That he might raise their expectations of the speedy performance of the promises made unto their fathers. Abraham, Isaac, and Jacob, are particularly named, because with Abraham the covenant was first made, and with Isaac and Jacob often expressly renewed.

YHWH yang adalah milik Israel dan bertindak bagi Israel, ialah Allah yang menjadi satu-satunya pemrakarsa pembebasan umat Israel. Dia Pembebas, menyertai bahkan kelak la memberikan tanah di Kanaan. YHWHlah yang telah bertindak bagi umat Israel, meski ada hal-hal tertentu yang dilakukan umat Israel untuk kebebasan mereka namun tidaklah sebanding dengan apa yang dilakukan YHWH bagi mereka, bahkan dapat dikatakan apa yang dilakukan bangsa Israel tidak akan ada artinya tanpa YHWH. Sedemikian besar perbuatan YHWH bagi umat Israel maka bukanlah sesuatu yang mengherankan jika umat Israel mengakui bahkan menceritakan turun temurun pekerjaan besar YHWH dalam sejarah bangsa Israel.

Jadi, ketika Allah menyatakan diri-Nya sebagai YHWH, Dia hendak berkata bahwa la ada dan bertindak bagi umat-Nya. la konsisten dan tidak akan mengingkari janji-Nya. YHWH adalah milik umat-Nya dan tidak akan membiarkan umat-Nya hancur dalam penindasan dan penderitaan. Semua YHWH lakukan dalam rangka pemeliharaan perjanjian-Nya. Beralasan jika Robert Letham dalam bukunya, Allah Trinitas menyebut YHWH sebagai Allah Kovenan. Allah yang tidak akan meningkari perjanjian-Nya.

\section{Allah Nenek Moyang mu}

(Elohe abtikem), meski dalam terjemahan baru diartikan sebagai "Allah nenek moyang mu" namun secara harfiah frasa ini memiliki arti Allah bapa-bapa mu, karena kata (abtikem) berasal dari kata ba yang memilki arti bapa dalam bentuk jamak dengan tambahan sufik sebagai kata tunjuk "mu". Demikian pula NIV dan KJV menterjemahkan dengan kata God Your Father. (Elohe) berasal dari kata El, tampaknya ini sebutan yang paling tua yang digunakan dalam menyebut nama Allah. Dari nama ini berkembang menjadi Elohim dan Eloah. Nama ini memiliki arti sebagai nama diri juga sekaligus gelar bagi Allah dan penggunaannya juga dipakai oleh bangsa-bangsa selain Israel. Nama El, Elohim atau Eloah menekankan bahwa Allah Pencipta ialah Allah yang mutlak atas ciptaan dan sejarah. Kata 'elohiym adalah bentuk Ibrani yang digunakan sekitar 2.570 kali dalam Perjanjian Lama dan biasanya diartikan sebagai suatu "kejamakan dari kemuliaan" dari nama umum untuk Allah. Nama itu berasal dari akar kata yang berarti "menjadi kuat" (Kej. 17:1; 28:3; 35:11; Yos. 3:10) atau "menjadi yang utama". Biasanya diterjemahkan "God" dalam terjemahan bahasa Inggris. Elohim menekankan ketransendenan Allah: la melampaui semua yang lain yang dipanggil Allah. Sebagian orang mengerti relasi El dan Elohim dalam arti Elohim sekedar sebagai bentuk jamak dari El; istilah ini rupanya dapat dipakai secara bergantian (Kel. 34:14; Mzm. 18: 32; Ul. 32:17; 21). Dalam beberapa bagian seperti di Yesaya 31:3, El menarik garis perbedaan antara Allah dengan manusia sehingga El menunjuk pada "kuasa dan kekuatan Allah dengan manusia dan ketidakberdayaan musuh manusia” (Hos. 11:9). (ab) artinya bapa, dalam teks ini jelas menunjuk pada leluhur Israel yang kepada mereka diikatkan sebuah perjanjian yang indah dan kepada bapa-bapa leluhur inilah pemeliharaan Allah yang sempurna dinyatakan. Kepada bapa leluhur dinyatakan jaminan keselamatan sekaligus kemenangan iman orang percaya. Hal ini dipastikan 
oleh Allah sendiri dengan mengikatkan dirinya terhadap sumpah kepada nenek moyang. Maka pengharapan umat Allah tidak akan sia-sia bahkan akan terus kokoh karena Allah tidak akan pernah ingkar janji.

Maka (Elohe abtikem), mau menjelaskan bahwa Allah yang bertindak bagi pembebasan Israel ialah Allah yang telah bertindak terhadap leluhur mereka. Allah yang telah mengikatkan janji terhadap bapa-bapa mereka dan terus memelihara umat Israel karena janji tersebut. Kembali Allah menekankan kesetiaan-Nya dalam frasa ini.

\section{Allah Abraham}

Abraham bapa orang percaya. Kepadanyalah janji Allah pertama kali dinyatakan bahwa keturunannya akan bertambah banyak dan jaminan khusus berupa tanah perjanjian akan diberikan (Kej.15:1-21). Kepada Abraham dan keturunannya janji itu dimulai dan terus-menerus dinyatakan, dibaharui dan ditepati.

Abraham dilahirkan dari keturunan Sem di tahun 2166 SM di tanah subur UrKasdim. Pada suatu waktu yang Tuhan tetapkan Abraham yang saat itu hidup dalam kemewahan materi dan penyembahan berhala dipanggil Allah untuk keluar dari Urkasdim berangkat ke Haran dan kemudian pada usia tujuh puluh lima tahun berangkat ke tanah Kanaan. Panggilan Allah kepada Abraham dari kaum penyembah berhala bukan hanya sebuah panggilan dan penyelamatan terhadap seseorang, lebih dari itu makna yang sangat penting dari panggilan tersebut ialah Allah menjadikan seorang Abraham sebagai bapa iman dan memulai keberangkatan baru untuk penebusan umat manusia. Pemilihan terhadap Abraham menjadi titik awal dimana janji keselamatan dinyatakan.

Menekuni panggilan tentu bukanlah suatu yang mudah tanpa rintangan. Abrahampun menghadapi masa-masa berat ketika berada di Haran dan Kanaan. Tidaklah mudah bagi Abraham meninggalkan keluarga dan tanah kelahirannya kemudian hidup kesepian sebagai pendatang. Kegelisahan Abraham menantikan keturunan tentu bukan merupakan sesuatu yang sederhana. Abraham seakan-akan dijanjikan sebuah harapan palsu. Bahkan dalam kitab Kejadian pasal 17, Abraham sempat menawarkan Ismael sebagai penerus perjanjian antara Allah dan Abraham, karena Abraham merasa dirinya terlalu tua untuk memiliki anak. Namun yang terjadi ialah Allah menembus segala kemustahilan untuk menggenapi apa yang dijanjikan-Nya. Kepedihan yang dialami Abraham tidak berhenti sampai disitu, ketika sang anak telah bertumbuh Allah menguji kesetiaan Abraham dengan meminta anak itu sebagai korban bakaran. Abraham taat dan apa yang Tuhan minta, sepenuhnya dilakukan oleh Abraham.

Sedangkan Allah Abraham ialah gelar Allah yang mengacu pada Tuhan Allah yang tertulis di Alkitab. Dengan menyatakan dirinya sebagai Allah Abraham Elohi Abraham, Allah menyatakan bahwa la akan setia pada perjanjian-Nya. Konsep perjanjian dalam agama kafir ialah para penyembah akan taat sepenuhnya kepada dewa mereka sebagai ganti kesejahteraan yang mereka rasakan dari dewa mereka. Namun jika berbicara mengenai Allah Abraham bukan hanya bicara mengenai kesetiaan Allah terhadap umat-Nya melainkan kesetiaan umat kepada Tuhan yang dinyatakan dalam hidup taat dan setia kepada Tuhan, sebagaimana Abraham hidup dengan setia, taat dan percaya kepada Allah dan perintah-perintah-Nya.

Frasa "Allah Abraham" sekaligus mengingatkan umat percaya bahwa Allah yang memampukan Abraham untuk melewati segala pergumulan kehidupannya. Allah 
YHWH pula yang memperkenankan Abraham menjadi bagian dalam keselamatan umat Israel. Dia satu-satunya Allah yang mampu menembus segala kemungkinan untuk terus memelihara umatnya dan menggenapi janji-Nya.

\section{Allah Ishak}

Melihat kelahiran Ishak dari sepasang orang tua yang sudah lanjut usianya bahkan dalam kitab Ibrani pasal 11:12 dikatakan bahwa ia akan dilahirkan oleh wanita yang "mati pucuk", merupakan suatu kelahiran yang unik namun amat penting karena melalui Ishaklah janji-janji Allah digenapi dan kemudian diteruskan kepada anak cucu. Konsistensi Allah dalam menepati janji-Nya kembali dinyatakan dalam kisah ini. Allah menembus segala kemustahilan untuk terus menepati janji-Nya.

Kisah perjalanan kehidupan Ishak mungkin tidak sedramatis Abraham ayahnya dan juga terkalahkan oleh kisah Yakub anaknya. Faktor lain yang mengurangi peranan Ishak ialah istrinya yang pandai mengendalikan orang lain namun itu tidaklah berarti bahwa iman Ishak lemah, kerjasama Ishak dengan Abraham dalam Kejadian 22 merupakan bukti bahwa Ishak juga memiliki iman dan ketaatan yang luar biasa seperti ayahnya. Namun Ishak tetaplah bagian dari perjanjian Allah karena ia mewarisi iman ayahnya jika tidak mustahil Ishak taat ketika akan dipersembahkan sebagai kurban.

Firman Allah kepada Abraham dalam Kejadian 15:4 "...melainkan anak kandungmu dialah yang menjadi ahli warismu”, dalam Kejadian 17:21 Allah juga berfirman "tetapi perjanjian-Ku akan Kuadakan dengan Ishak, yang akan dilahirkan Sara bagimu tahun yang akan datang”. Jelaslah bahwa Ishak menjadi generasi sejati yang melanjutkan iman Abraham.

\section{Allah Yakub}

Yakub ia lahir dengan memegang tumit saudara kembarnya Esau, maka nama Yakub sendiri memiliki makna "dia memegang" dapat juga diartikan sebagai penipu. Arti nama ini tampaknya melekat pada kehidupan Yakub yang sanggup melakukan apapun untuk apa yang ia inginkan. Memanfaatkan keadaan Esau yang sedang lapar dan meremehkan hak kesulungannya (Kej. 25:34). Maka Yakub bekerja sama dengan ibunya menipu Ishak untuk beroleh berkat kesulungan. Untuk hal ini Yusak Susabda berpendapat:

Yakub adalah: licin. Dia sangat licik, penuh akal, ahli dalam tipu menipu dan layak digelari tukang tipu. Bagaimana sepak terjangnya? Dia lari dari rumah karena menipu ayahnya, Ishak, dengan berpura-pura menjadi Esau untuk merebut hak kesulungan (Kej. 27). Ketika sampai di Betel dia bermimpi malaikat-malaikat Allah turun naik di tangga yang ujungnya sampai di langit serta TUHAN berfirman kepadanya (Kej. 28:10-18) tetapi ia tidak berubah, hatinya tetap penuh kelicikan. Dia menjadi semakin kaya dan melupakan panggilan TUHAN hingga TUHAN mengingatkan dan memerintahkan dia untuk kembali pulang ke negeri nenek moyangnya (Kej 31:3,13). Di dalam perjalanan pulang, dia menyaksikan malaikatmalaikat TUHAN menyertainya (Kej. 32) tetapi hal itu tidak dapat menenangkan hatinya. Yakub masih meragukan penyertaan TUHAN apalagi saat dia harus melewati tanah Edom tempat kakaknya tinggal. Dia sangat ketakutan membayangkan kemarahan kakaknya akibat perbuatan liciknya dahulu bisa jadi Esau akan membunuhnya. Dalam kondisi terjepit Yakub menjadi orang yang sangat jahat. Dia tidak hanya 'menyuap' kakaknya dengan harta kekayaan tetapi juga rela mengorbankan istri-istri, gundik dan anak-anaknya (Kej. 33:2). Meski terjadi dalam tipu daya, berkat yang telah diberikan tidaklah dapat ditarik lagi 
maka Yakub menjadi pewaris perjanjian yang telah diikat Allah kepada Abraham dan Ishak.

Yakub mengalami titik balik dalam kehidupannya saat ia bergulat dengan Tuhan. Saat itu ia mengalami kehancuran secara fisik dan emosi. Secara fisik, Yakub pincang karena malaikat Tuhan memukul sendi pangkal pahanya sedangkan secara emosi, Yakub harus mengakui keberadaan dirinya sebagai penipu yang telah menjadi karakternya, sesuai dengan namanya Yakub, yang artinya penipu. Setelah pengalaman rohaninya bersama Tuhan, Yakub yang berganti nama menjadi Israel mulai menggenapi rencana Tuhan dalam hidupnya. Allah bukan hanya berperan aktif dalam pergumulan yang dialami Yakub bahkan memakai semua penderitaan yang dialami Yakub untuk memulihkan dan mengubahkan kehidupan Yakub.

\section{Respon Terhadap Penyataan Allah}

Allah yang menyatakan Diri-Nya melalui nama-Nya tentu harus diresponi umat agar kemahabesaran Allah itu dapat dirasakan oleh banyak orang. Maka dalam penyataan dirinya la menyatakan mengharapkan respon umat melalui kata, selamalamanya, sebutanku dan turun-temurun.

Mengimani Janji Allah Yang Selama-lamanya dalam teks ini menggunakan kata (Le olam) dari kata dasar (olam) yaitu forever, ever, everlasting, evermore, perpetual, old, ancient, world. Digunakan sebanyak tiga ratus kali dalam Alkitab untuk menterjemahkan kekekalan, yaitu sebuah masa yang tidak dapat ditentukan batas akhir waktunya, terus menerus atau sesuatu yang tidak berakhir. Durasi waktu dalam kata olam ialah durasi yang tidak dapat dipecahkan manusia.

Melalui kata ini kembali Allah menegaskan konsistensi-Nya kepada umat Israel. Apa yang sudah dinyatakan melalui nama-Nya itu kekal dan tidak akan berubah. Maka umat haruslah mengimani janji Allah selama-lamanya dengan setia dan tidak berpaling sedikitpun dari janji itu. Berjalan dalam penderitaan bukanlah sesuatu yang mudah, berharap ketika seakan tidak ada harapan ialah sesuatu yang berat namun Allah mengharapkan konsistensi dalam menggantungkan harapan kita hanya pada-Nya. Karena karya Allah kekal maka melalui kekekalan karya Allah itu umat dibawa pada kesetiaan kepada Allah.

\section{Mengingat apa Sebutan Allah}

"Sebutan ku..." (zeh zakar) dalam teks Kel. 3:15 merupakan bentuk respon yang diinginkan Tuhan yang memiliki makna literal, ingatlah ini. Kata zakar diterjemahkan sebagai: think (about), meditate (upon), pay attention (to); remember, recollect; mention, declare, recite, proclaim, invoke, commemorate, accuse, confess. Secara sederhana diterjemahkan dengan kata mengingat. Namun Theological Word old Testament memberikan makna yang lebih spesifik yaitu:

There are three groups of meanings: 1) for completely inward mental acts such as "remembering" or "paying attention to", 2) for such inward mental acts accompanied by appropriate external acts, and 3) for forms of audible speaking with such meanings as "recite" or "invoke."

Bahwa sebutan yang dimaksud bukanlah sesuatu yang hanya keluar dari bibir, melainkan direnungkan dan diingat. Allah mau nama-Nya diresponi umat dengan terus menerus mengingat perbuatan-Nya yang besar, ajaib dan agung. Dan lebih dari itu 
umat juga diharapkan mewujudnyatakan ingatan mereka dalam suatu tindakan nyata. Mereka mengingat, mengimani dan menceritakan perbuatan Allah yang besar dalam hidup mereka ketika mereka menyebut nama Allah.

\section{Mengajarkannya secara turun-temurun}

Turun-temurun (le dor-dor), secara harafiah diterjemahkan generasi ke generasi, berkaitan dengan kata dor. Theological Wordbook of Old Testament, membagi pemaknaannya dalam enam penggunaan, yaitu:

1. The circle of a man's lifetime, from birth to death.

2. More frequently, of the circle of a man's life from his conception and birth until the conception..

3. A period or age of time.

4. One group as opposed to a single person as related to another by natural descent (Jud 2:10).

5. A special use of the fourth sense above is to mean simply "contemporaries" "and of his generation, who considered"? (Isa. 53:8, Gen 6:9).

6. By a natural transition this word is used widely with a metaphorical sense to indicate a class of men distinguished by a certain moral or spiritual character.

Melalui makna diatas kita dapat melihat bahwa, ketika Allah menyatakan bahwa sebutan-Nya tetap turun temurun, bukan hanya generasi Israel sebagai objek kasihNya, melainkan juga periode jangka waktu yang amat panjang Dia menyatakan kasihNya, jaman lepas jaman Allah tetaplah Allah. Selama manusia hidup maka Allah tidak akan berubah,"... one of concrete meaning of "dor" is a period during wich people life". Penyertaan Sempurna sepanjang zaman itulah makna utama dari kata dor.

Ini merupakan durasi dari semua janji Allah kepada umat Israel yaitu kekekalan dan akan tetap konsisten kepada semua umat disegala waktu. Maka umat harus meresponi janji Allah itu dengan mengajarkan dari generasi ke generasi, waktu lepas waktu. Agar mereka sadar bahwa Allah setia sampai kapanpun dalam kondisi apapun.

\section{Kesimpulan}

Allah yang menyatakan diri-Nya dengan nama-Nya, ialah Allah yang setia. Maka dengan menyatakan namanya Dia hendak berkata bahwa Dia ada bahkan bertindak bagi umat-Nya dalam segala situasi. Allah setia akan janji-Nya maka tidak sedetikpun la berpaling dari umat-Nya. Namun untuk meresponi kasih dan pemeliharaan yang luar biasa itu baiklah umat yang dikasihi, setia pada-Nya. Keluarbiasaan kasih-Nya itu menjadikan suatu berita sukacita yang terus menerus dibagikan kepada orang lain. Agar banyak jiwa-jiwa juga turut merasakan kebesaran Allah itu dan la semakin ditinggikan. Umat pun diharapkan meresponi dengan baik apa yang sudah Tuhan perbuat dan umat diharapkan konsisten terhadap iman kepada Tuhan.

Penderitaan dan penindasan merupakan suatu hal yang identik dengan keKristenan. Tidak dapat dipungkiri seringkali penindasan tersebut menjadi kekuatan tersendiri bagi orang percaya untuk terus bertumbuh dan menghasilkan buah. Semakin dibabat semakin merambat, suatu semboyan yang mewakili sifat kekristenan, menunjukan bahwa penderitaan tidak sedikitpun menyurutkan iman orang percaya.

Ketika penderitaan dan penindasan fisik yang dialami sejak masa sejarah gereja hingga masa kini terbukti dapat menjadi penggerak bagi kemajuan Injil dan iman orang 
percaya. Namun apakah hal yang sama akan terjadi jika penderitaan yang dimaksud ialah penderitaan yang dalam dunia teologia disebut dengan masa tribulasi. Penderitaan pada masa tribulasi merupakan suatu penderitaan yang lebih kompleks, dimana pada masa tribulasi penderitaan akan sangat menyengsarakan setiap orang percaya, kondisi ini akan diperparah dengan pemerintahan antikristus yang akan memaksa orang pecaya menyangkali iman mereka, melalui tekanan ekonomi yang menjadi kekuasaan antikristus. Kelak pada masa tribulasi pembunuhan dan penindasan terhadap orang percaya akan menjadi suatu hal yang umum bagi dunia masa itu. Bukan tidak mungkin orang percaya akan melihat orang yang dikasihi dibunuh dihadapan mata mereka sendiri.

Melihat kenyataan bahwa penderitaan tersebut sangat berat dan cenderung mengakibatkan penyangkalan iman bagi orang percaya, maka perlu digali dari Keluaran 3: 15, yaitu penyataan diri Allah melalui nama-Nya. Maka dengan memahami makna penyataan diri Allah melalui nama-Nya. Allah yang menyatakan Diri-Nya melalui nama-Nya membuktikan eksistensi-Nya. Ketika la meletakkan nama-Nya pada nama bapa leluhur Allah mau menegaskan bahwa la adalah satu-satunya jaminan dari perjanjian yang la prakarsai. Meski la menyatakan diri-Nya pada masa sulit namun sesungguhnya penyertaan Allah sempurna sepanjang masa. YHWH ialah nama yang dinyatakan Allah sendiri kepada umat-Nya dan hal ini dituliskan didalam Alkitab yang adalah sumber dari segala kebenaran. Dalam penindasan yang dialami oleh umat pilihan, Allah menyatakan diri-Nya dengan nama YHWH. Melalui penyataan diri Allah dalam nama YHWH umat Allah diperkenankan untuk mengenal, mengetahui bahkan memanggil nama itu. Maka melalui nama itu nyata bahwa Allah ada untuk umat-Nya, bangsa pilihan yang sedang dalam penindasan akan dibebaskan oleh $\mathrm{YHWH}$ yang adalah milik mereka. YHWH yang maha dahsyat akan menjadi pembebas bagi semua orang yang mengasihi-Nya.

Lebih-lebih sekarang bahwa Kristus telah menjadi bukti nyata kasih dan Immanuel penyertaan yang sempurna dan oleh Roh Kudus yang setia memimpin umat-Nya maka nama YAHWEH menjadi selalu ada sepanjang masa hingga sampai sekarang.

Jadi melalui pemahaman terhadap nama Allah orang percaya diingatkan bahwa pembebasan akan nyata dalam setiap penderitaan yang akan dialami. Pembebasan yang dimaksud tentu bukan hanya sebatas pembebasan fisik melainkan juga pembebasan secara rohani yaitu hidup kekal bersama dengan Allah. Ketika menghadapi masa tribulasi bisa saja orang percaya mati, namun tidak berarti akan binasa dalam kesia-siaan karena YHWH dalam Yesus Kristus akan menjadi pembebas orang percaya secara rohani. Dengan pemahaman inilah orang percaya dikuatkan kembali untuk terus berpengharapan pada Allah. Allah setia dalam kehidupan umat percaya sehingga Allah sendiri dengan aktif ambil bagian dalam kehidupan manusia. Kedalaman makna dari penyataan Allah melalui nama-Nya, akan membuat orang percaya sadar akan kekuatan Allah yang siap menopang kehidupan orang percaya untuk melewati setiap penderitaan. Pemahaman ini menurut penulis sangat signifikan karena menjadi jaminan bagi orang percaya dalam menghadapi masa tribulasi. 


\section{Kepustakaan}

Buku

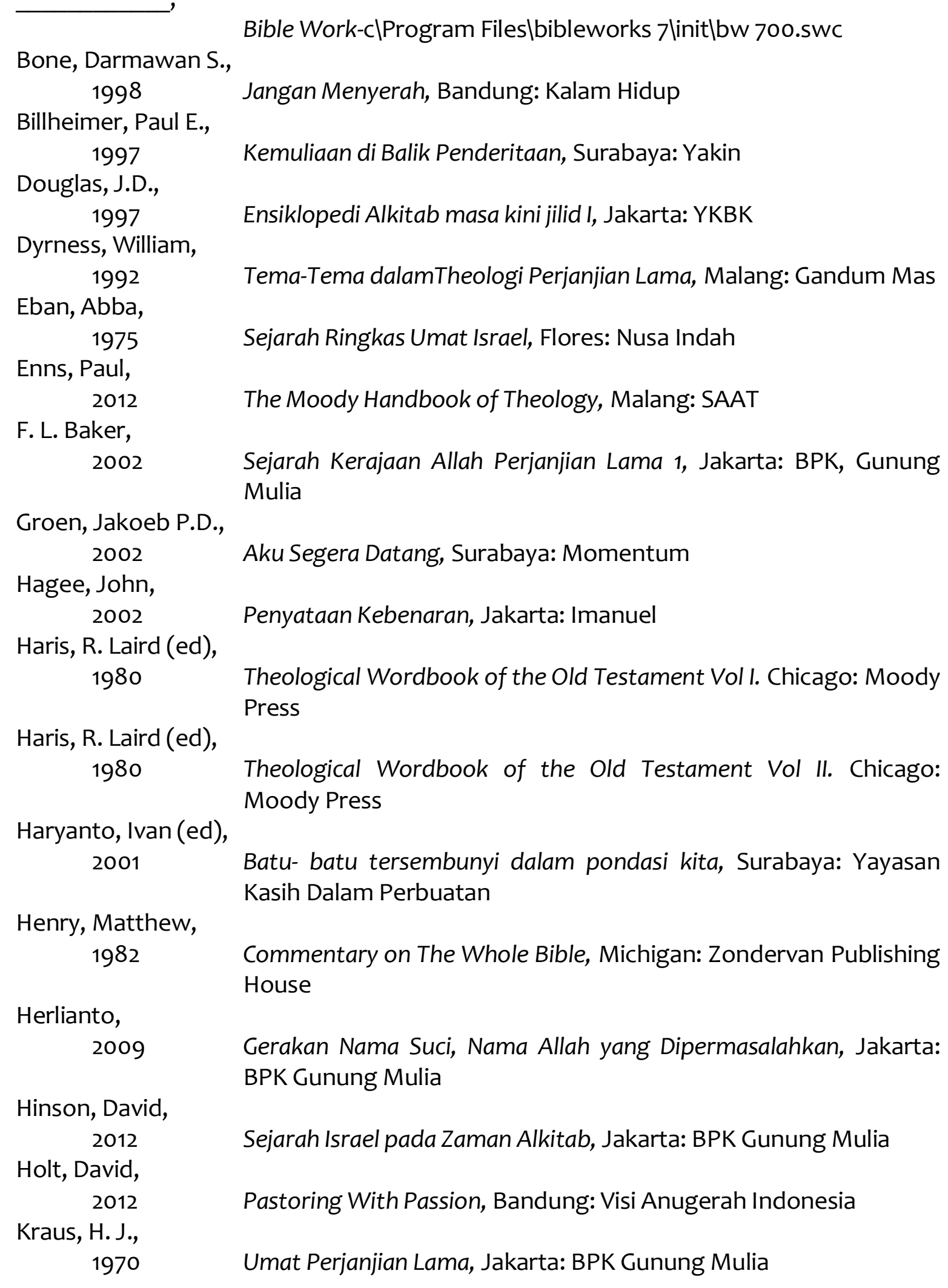


Oktavianus, Petrus,

Tt

Alih Generasi Kepemimpinan dalam garis Firman Allah, Malang: POI Owen, John Joseph,

1994

Analytical Key to Old Testament Vol 1, Michigan: Baker Book House

Pandensolang, Welly,

2004 Eskatologi yang Biblika, Yogyakarta: ANDI, 2004

Parcker, J.,

1995 Ensiklopedi Fakta Alkitab 1, Malang: Gandum Mas

Park, Abraham,

2011

Pertemuan Yang Terlupakan, Jakarta: Yayasan Damai Sejahtera Utama

Park, Abraham, 2011

Pelita Yang Tidak Terpadamkan, Jakarta: Yayasan Damai Sejahtera Utama

Piper, John., 2008 Kesukaan Allah, Surabaya: Momentum

Rosin, H., 2002

Tafsir kitab Keluaran 1-12:21, Jakarta: BPK Gunung Mulia

Rothlisberger, $\mathrm{H}$., 1965 Firmanku Seperti Api, Jakarta: BPK Gunung Mulia

Ryrie, Charles C., 1999 Waktunya Sudah Dekat, Malang: Kalam Hidup.

Ungger, Merril .F., (ed).

1980 Exspository Dictionary of the Old Testament, Nashvile: Thomas Nelson Publisher

Vine, W.E., dkk., 1985

Vine's Complete Expository Dictionary of Old and New Testament Words New York: Thomas Nelson Publishers

Vriezen, Th., 2003 Agama Israel Kuno, Jakarta: BPK Gunung Mulia

Wahono, Wismoady, 1981 Dua Study Tentang Hubungan Tuhan dengan Israel, Jakarta: BPK Gunung Mulia

Webster,

1967 Webster's New Practical School Dictionary, California: California State Series

Wilangga, Yunus Cipta,

$2014 \quad$ Lima gadis bodoh dan lima Gadis Bijaksana, Bandung: Terang Hidup

Wilangga, Yunus Cipta,

2014 Pelayanan yang Paling Utama, Bandung: Terang Hidup

Wongso, Peter, $1989 \quad$ Hermeneutika Eskatologi, Malang: SAAT

Zodhiates, Spiros, 1993

The Completle Word Study Dictionary of the New Testament, Chattanooga: AMG Publisher 
Zuck, Roy B., (ed), 2005 A Biblical Theologi of the Old Testament, Malang: Gandum Mas

Internet

2014 ChristianAnswers. Net/Indonesian, searching 19 Desember 2014

2014

www.nathionalgeographic.co.id, searching tgl 17 Agustus 2014

www.republika.co.id, searching tgl 17 Agustus 2014

www.shotusalam.com, searching tgl 17 Agustus 2014

jers8558.blogspot.com/ searching 31 Juli 2014 